\title{
READY-TO-EAT PRODUCTS FROM SWEET POTATO AND PUMPKIN
}

Amal A. Matar*; Nahed S. Yousef*; M. Q. Hassanein ${ }^{\star \star}$ and Amena M. El-Nahal*

* food science and technology dpartment, Fac.of Home economic., AlAzhar University, Egypt.

${ }^{\star *}$ Central laboratory of Agriculture Climate,Agriculture Research Center, Egypt.

\begin{abstract}
In this study, sweet potato and pumpkin were pre-treated and dried to obtain ready-to-eat products. Four different pre-treatments were performed as follows, untreated as control (A), dipping in boiling water (B), dipping in 15\% sugar solution at $70^{\circ} \mathrm{C}(\mathrm{C})$ and dipping in $1 \%$ sodium metabisulphite solution (D). These pre-treatment samples were dried with different drying methods. These methods include solar drying, sun drying and oven air drying. The maximum temperature difference between inside and outside solar dryer was as high as $21.8^{\circ} \mathrm{C}$. Likewise, the inside relative humidity is lower than the outside solar dryer and maximum differences were as high as $19.4 \%$. Solar drying period for all tested samples ranged between 52 to $58 \mathrm{hrs}$ with $8-12 \%$ moisture content, while 63 to $97 \mathrm{hrs}$ were needed to dry all tested samples by sun drying to reach the same moisture content. On the other hand, oven air dryer required only 6 hours for all tested samples.

Data given in this study showed the effect of pre-treatment, drying methods and storage period at ambient temperature for 6 months on moisture content, total sugars, reducing sugars and acidity as citric acid of dried samples. Results showed that pretreatment sample with $15 \%$ sugar solution and sodium metabisulphite increased water removal in all samples. Data represent indicated that more total sugars and reducing sugars were observed in untreated samples for all drying method. Also, data obtained showed that more increasing in acidity for samples were treated with sodium metabisulphite compared with the other samples. Solar drying was observed to product relatively better product in terms of nutrient composition compared to sun drying. Drying was faster with the use of the solar drier than sun drying. Solar drying produced samples with lower moisture content. Organoleptic evaluation of the dried samples was also performed, including of color, taste, odor, texture and acceptability.
\end{abstract}

Keywords: Ready-to-eat products, snack food and drying method

\section{INTRODUCTION}

Ready to eat snack is portion of food often times smaller than that of a regular meals, that is generally eaten between meals. Processed snack foods as designed to less perishable, more durable than prepared food. Snack foods play very important roles in the diet of the modern consumer. The snack food industry continually searches for products and processes that increasingly please consumers and addresses nutritional concerns, sometimes, only to find limited demand or acceptance in the marketplace. Such was the case for snacks with reduced salt content, use of non-caloric frying oils and low-fat/no-fat snacks (Lusan and Rooney, 2002).

Over $60 \%$ of consumers eat snacks purely for enjoyment. Healthier snack products continue to do well, increasing by $3 \%$ in 2009 over the 
Amal A. Matar. et. al.

previous year, and up by $8 \%$ since 2005 . In fact, $83 \%$ of consumers claim they eat snacks for their nutritional benefit and $40 \%$ seek benefits beyond basic nutrition.

Children are especially vulnerable to poor food choices and obesity is increasing at an alarming rate in children (Strauss and Pollack, 2001). Snack food consumption is increasing and may contribute to the obesity epidemic (Nielson et al., 2002). Sweet potatoes (Ipomoea batatas) are traditionally sundried in Africa for consumption in the dry season when fresh roots are not available. Dried pieces can be re-hydrated or milled into flour to be used in porridge. In urban areas, flour can also be used in a variety of baked products to partially replace wheat flour (Bechoff et al., 2009). Pumpkins (Cucurbita mixta) are relatively low in total solids, usually ranging between $7 \%$ and $10 \%$ (Are'valo-Pinedo and Fernanda, 2006). It is good sources of carotenoids, and some varieties are rich in provitamins A, mainly á-carotene and â-carotene (Marek et al., 2008). Thus maintaining pumpkin in a state that retains its actual nutrients, taste and color is a difficult task. Drying is the common method used for its preservation and it is commonly done by utilization of sun energy in places where pumpkin is being dried (Tunde-Akintunde and Ogunlakin, 2011). Guin'e et al. (2011) found that Fresh pumpkin contained $52.84 \%$ total sugar,( $26.35 \%$ reducing sugar, $25.12 \%$ non reducing sugars), $13.99 \%$ Ash and $12.24 \%$ fiber.

The objective drying is the removal of water to the level at which microbial spoilage and deterioration reactions are greatly minimized (Akpinar and Bicer, 2004). It is also provides longer shelf-life smaller space for storage and lighter weight for transportation (Ertekin and Yaldiz, 2004).

Jain and Tiwari (2004) reported that the convective mass transfer coefficient in greenhouse drying under forced mode is double that of natural convection in the initial stage of drying. Further, the electric power requirement of the fan in case of forced convection solar driers is very low and can be operated by one photovoltaic module independent of the electric grid (Bala et al., (2005), Chen et al., (2005) and Hossain \& Bala, (2007).

Advantages of solar driers that enable them to compete with traditional open-air sun drying techniques and/ or artificial driers powered by energy from fossil fuels have been previously reported in the literature by many researchers (Hossain and bala, 2007). Further, more than $80 \%$ of food in developing countries is being produced by small farmers and design of most solar driers can fulfill their needs (Murthy, 2009)

Mechanical pretreatment might replace or complement chemical pretreatment, mainly because consumers hesitate to buy chemically treated fruits, and it has a profound effect on the later drying process. Mechanical pretreatment consists of peeling, surface abrasion, and cutting in various shapes, such as halves, cylinders, and cubes. A number of researchers (Shi and Maupoey, 1993; Jia et al., 1993 and Kiranoudis et al., 1997) used some kind of mechanical treatment to accelerate mass transfer in subsequent processing. There are several methods that can be applied (Beaudry, 2001), puncture the skin by a needle, cut the berry in halves or quarters, and abrade the skin surface. All these mechanical pretreatments are used to increase the "active" skin surface where water can penetrate. The objectives of this work 
to make the available of snack foods on the market ready-to-eat and study the effect of pre-treatment and drying methods on characteristics of tested sweet potato and pumpkin

\section{MATERIALS AND METHODS}

Sweet potato (Ipomoea batatas) and pumpkin (cucurbita pepol) were obtained from the local market in Tanta city, Gharbia Governorate, Egypt. Sweet Potato and pumpkin were washed with tap water and then hand peeled, cut into cubes of dimensions $15 \times 10 \times 10 \mathrm{~mm}$. Four different pretreatments were: Untreated as control (A), dipped in boiling water for 4-5 min (B), dipped in $15 \%$ sugar solution for 5 min at $70^{\circ} \mathrm{C}(\mathrm{C})$ and dipped in $1 \%$ sodium metabisulphite solution for 2 min (D). Samples were drained well and blotted with absorbent paper to remove the excess solution. Samples were placed in a single layer on the drying trays before drying to final moisture content of 8-12\% (Bilbao-Sainz et al., 2005).

All treated samples were dried by using oven air drier, sun and solar dryer. The solar dried used was a direct cabinet type with natural air circulation which are used generally for drying agricultural products (Reuss, 1993). The solar dryer was manually assembled from wood and polyethylene cover with five Seran shelves. The drying experiments were conducted during three days in July.

For comparison, an electrical oven air drier was used for seven hours, with a pre-set temperature of $60^{\circ} \mathrm{C}$. After the drying process the samples were put into polyethylene bags and stored for six months (Rosa Hemphill1 and Lloyd W. Martin (1992).

Two dry and wet-bulb air temperature sensors were installed near the bottom and near the top inside the solar dryer as well as another set that was installed at $2 \mathrm{~m}$ height outside the dryer using type-T thermocouples (Medany et al., 1996). All sensors were connected to a 21X data logger (Camplle Scientific Inc., Utah, USA) which was programmed to store one reading at the top of each hour. The sensors were calibrated before and after the experiments. Hourly wet bulb readings were converted to relative humidity according to the methods described by ASAE (1991).

Determining the rate of drying $(R d)$ during the process based on moisture content level has given the relation:

Whereas:

$$
R d=\frac{M i-M d}{T}
$$

$M_{i}$ and $M_{d}$ are the initial and final moisture content, $T$ is the drying time in hour (Wankhade, et al., 2012).

Temperature difference, ${ }^{\circ} \mathrm{C}={ }^{\circ} \mathrm{C}$ inside $-{ }^{\circ} \mathrm{C}$ outside dryer

Relative humidity difference $(\mathrm{RH}) \%=\mathrm{RH}$ inside $-\mathrm{RH}$ outside dryer

Moisture content,total soluble solid, fat, protein fiber, total sugar, reducing sugar, ash and acidity as citric acid were determined according to the methods described by A.O.A.C (2000).

A trained 12 members panel of students in the faculty of home economics department of science and technology feed Al-Azhar University 
Amal A. Matar. et. al.

evaluated the samples using a scale of 1 to 10 , where 1 were the lowest and 10 the highest intensity for all. The evaluated parameters taste, colour, flavor, texture and overall acceptability (McWilliams 1997).

The results were statistically analyzed by analysis of variances as described by SPSS (1997). Significant differences among individual means were analyzed by Duncan's multiple range tests (Duncan's, 1955).

\section{RESULTS AND DISCUSSION}

The chemical composition of sweet potato and pumpkin are given in Table 1. It was noticed that all chemical constituents were higher in sweet potato than pumpkin except moisture content. moisture contents were $70.8 \%$ in sweet potato and $92.0 \%$ in pumpkin.

From Table 1, it was observed that, total soluble solids recorded $27 \%$ meanwhile in pumpkin was $6.32 \%$. Reducing and non-reducing sugar were 8.22 and $9.76 \%$ in sweet potato, but 2.79 and $2.40 \%$ in pumpkin, respectively.

Data showed that, sweet potato recorded higher values in ash $(2.46 \%)$ than pumpkin $(0.81 \%)$. The acidity measured as citric acid in sweet potato and pumpkin was 0.09 and $0.06 \%$. Protein recorded high in sweet potato and pumpkin; it was 2.13 and $1.3 \%$, respectively. The previous results were in agreement with those found by Ishida et al. (2000); Rodrigues et al. (2003); D'ıaz-Medina et al. (2007) and Guin'e et al. (2011).

Table (1): Chemical composition (\%) of fresh sweet potato and pumpkin $(w / w)$

\begin{tabular}{|l|c|c|}
\hline \multicolumn{1}{|c|}{ Chemical constituents } & Sweet-potato & Pumpkin \\
\hline Moisture & 70.8 & 92.0 \\
\hline Total soluble solid & 27.0 & 6.32 \\
\hline Fat & 0.19 & 0.1 \\
\hline Protein & 2.13 & 1.2 \\
\hline Fiber & 5.97 & 0.7 \\
\hline Reducing sugar & 8.22 & 2.79 \\
\hline Non reducing sugar & 9.76 & 2.40 \\
\hline Ash & 2.64 & 0.81 \\
\hline Acidity as citric acid & 0.09 & 0.06 \\
\hline
\end{tabular}

During Julian days (213 to 218), time needed to reach the moisture content to $8-12 \%$ of sun, solar and oven air dried of pumpkin and sweet potato showed in Table (2) and Figure (1). Data in Table (2) showed that sun drying time for sweet potato was 90-97 hrs for four treated samples (A, B, C and D). On the other hand, it was 53-56 hrs for solar drying (Fig. 1). Pumpkin drying time took 63-67 hrs in the sun (Fig. 1) and 52-58 hrs in solar dryer for four treated samples (A, B, C and D).

A sharp decrease in moisture content was noticed in the first day for all treatments however, in second and third day showed slow rate of dehydration (Fig. 1). It proved that solar dryer could speed up the removal of moisture content because of the existence of a collector which can increase the temperature inside the box (cabinet). It was found that all tested samples, dried by hot air drying were reported to take minimum time for drying. Figure 
(1) showed that oven drying time was $5-6 \mathrm{hrs}$ in order to reach $8-12 \%$ moisture content in the sweet potato and pumpkin samples at temperature of $60{ }^{\circ} \mathrm{C}$, with a sharp decrease in the moisture content during the first 3 hours. These results were in agreement with those of Yousef and Medany (2007) who dried banana, mango, guava and carrot using sun, solar and hot air drying.
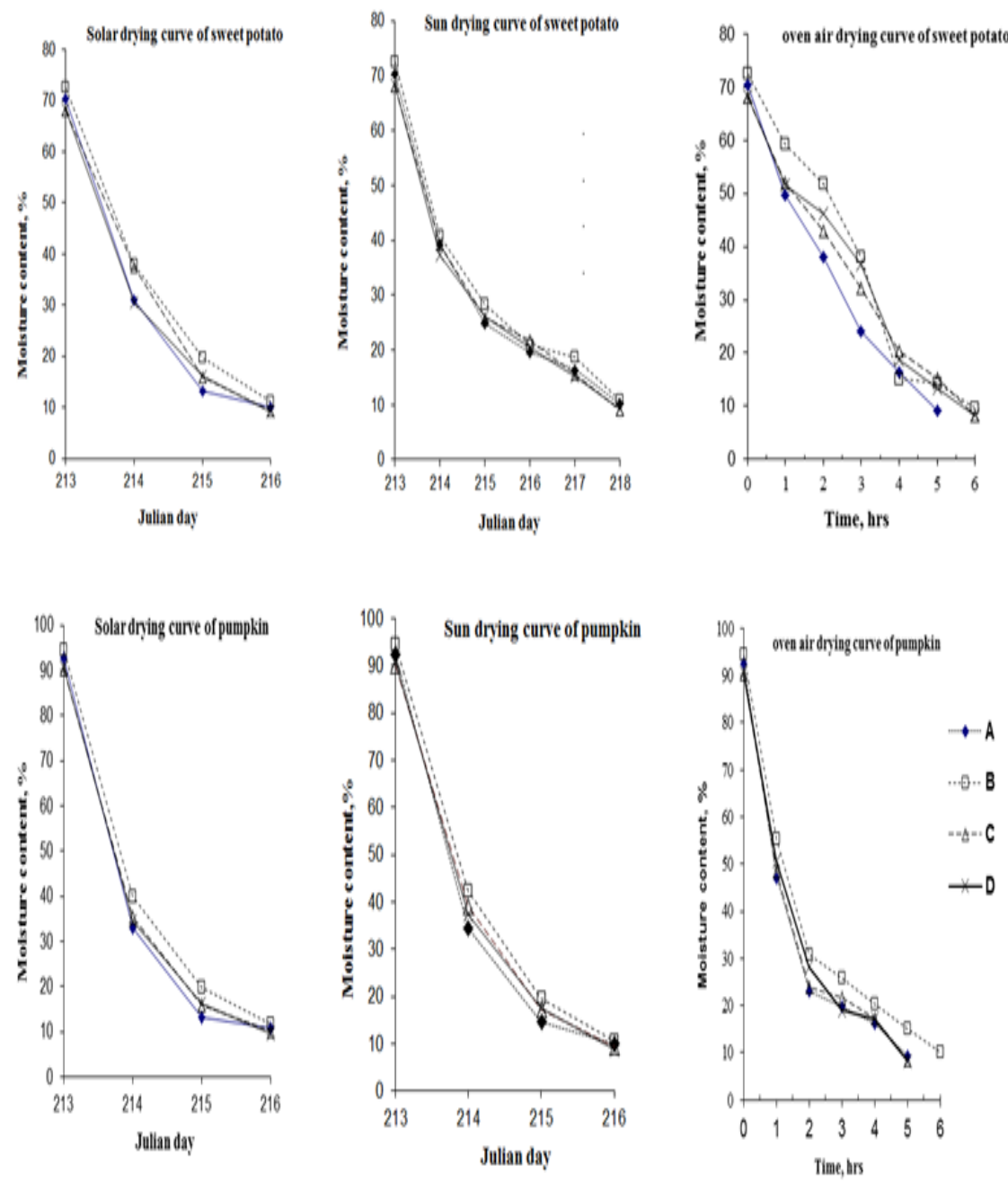

$A=$ Untreated (control)

C = Dipped in $15 \%$ sugar solution

for $5 \mathrm{~min}$ at $70 \mathrm{C}$

$D=$ Dipped in $1 \%$ sodium metabisulphat for 2 min

Fig.(1):Drying methods curves of sweet potato and pumpkin 
Amal A. Matar. et. al.

Table (2): Drying rate of different drying methods on respective moisture content of dried tested samples.

\begin{tabular}{|c|c|c|c|c|c|}
\hline Drying methods & Treatments & $\mathbf{M}_{\mathbf{i}}$ & $\mathbf{M}_{\mathbf{d}}$ & $\mathbf{t}$ & $\mathbf{R}_{\mathbf{d}}$ \\
\hline \multirow{10}{*}{ Solar drying } & Sweet potato & & & & \\
\hline & A & 70.4 & 10.04 & 53 & 1.14 \\
\hline & B & 72.6 & 11.2 & 56 & 1.10 \\
\hline & $\mathrm{C}$ & 68.2 & 9.41 & 54 & 1.09 \\
\hline & $\mathrm{D}$ & 68.4 & 9.24 & 55 & 1.08 \\
\hline & Pumpkin & & & & \\
\hline & A & 92.6 & 10.92 & 52 & 1.57 \\
\hline & $\mathrm{B}$ & 94.4 & 11.95 & 58 & 1.42 \\
\hline & $\mathrm{C}$ & 90.2 & 10.29 & 54 & 1.48 \\
\hline & $\mathrm{D}$ & 90.6 & 10.59 & 55 & 1.45 \\
\hline \multirow{10}{*}{ Sun drying } & Sweet potato & & & & \\
\hline & $A$ & 70.4 & 10.11 & 90 & 0.67 \\
\hline & $\mathrm{B}$ & 72.6 & 10.77 & 97 & 0.64 \\
\hline & $\mathrm{C}$ & 68.2 & 9.03 & 93 & 0.64 \\
\hline & $\mathrm{D}$ & 68.4 & 9.31 & 94 & 0.63 \\
\hline & Pumpkin & & & & \\
\hline & A & 92.6 & 10.14 & 63 & 1.31 \\
\hline & $\mathrm{B}$ & 94.4 & 11.56 & 67 & 1.24 \\
\hline & $\mathrm{C}$ & 90.2 & 9.5 & 65 & 1.24 \\
\hline & $\mathrm{D}$ & 90.6 & 8.74 & 64 & 1.28 \\
\hline \multirow{10}{*}{ Oven air drying } & Sweet potato & & & & \\
\hline & $A$ & 70.4 & 9.24 & 5 & 12.23 \\
\hline & $\mathrm{B}$ & 72.6 & 9.63 & 6 & 10.50 \\
\hline & $\mathrm{C}$ & 68.2 & 8.32 & 6 & 9.98 \\
\hline & $\mathrm{D}$ & 68.4 & 8.12 & 6 & 10.05 \\
\hline & Pumpkin & & & & \\
\hline & $A$ & 92.6 & 9.41 & 5 & 16.64 \\
\hline & $\mathrm{B}$ & 94.4 & 10.19 & 6 & 14.04 \\
\hline & $\mathrm{C}$ & 90.2 & 8.39 & 5 & 16.36 \\
\hline & $\mathrm{D}$ & 90.6 & 8.33 & 5 & 16.45 \\
\hline
\end{tabular}

$M_{d}=$ final moisture content, \% $\quad R_{d}=$ rate of drying (\% m.c./hr)

The amount of evaporated water during the night was lower than that during the day and this was due to the variations between the day and night temperatures (Fig. 2). The previous results were in agreement with those found by Ukegbu and Okereke (2013). The drying curves for all B samples are higher than $A, C$ and $D$ samples, because of blanching increased the initial moisture content of the sweet potato and pumpkin from $70.2 \%$ to 72.4 $\%$ and $92.2 \%$ to $94.6 \%$, respectively (Table 2 ). These results were in agreement with those of Tunde-Akintunde et al. (2005) who dried bell-pepper using sun, solar and hot air drying.

An examination of these curves indicate that the drying of control samples $(A)$ is faster than treated samples $B, C$ and $D$ which is the same 


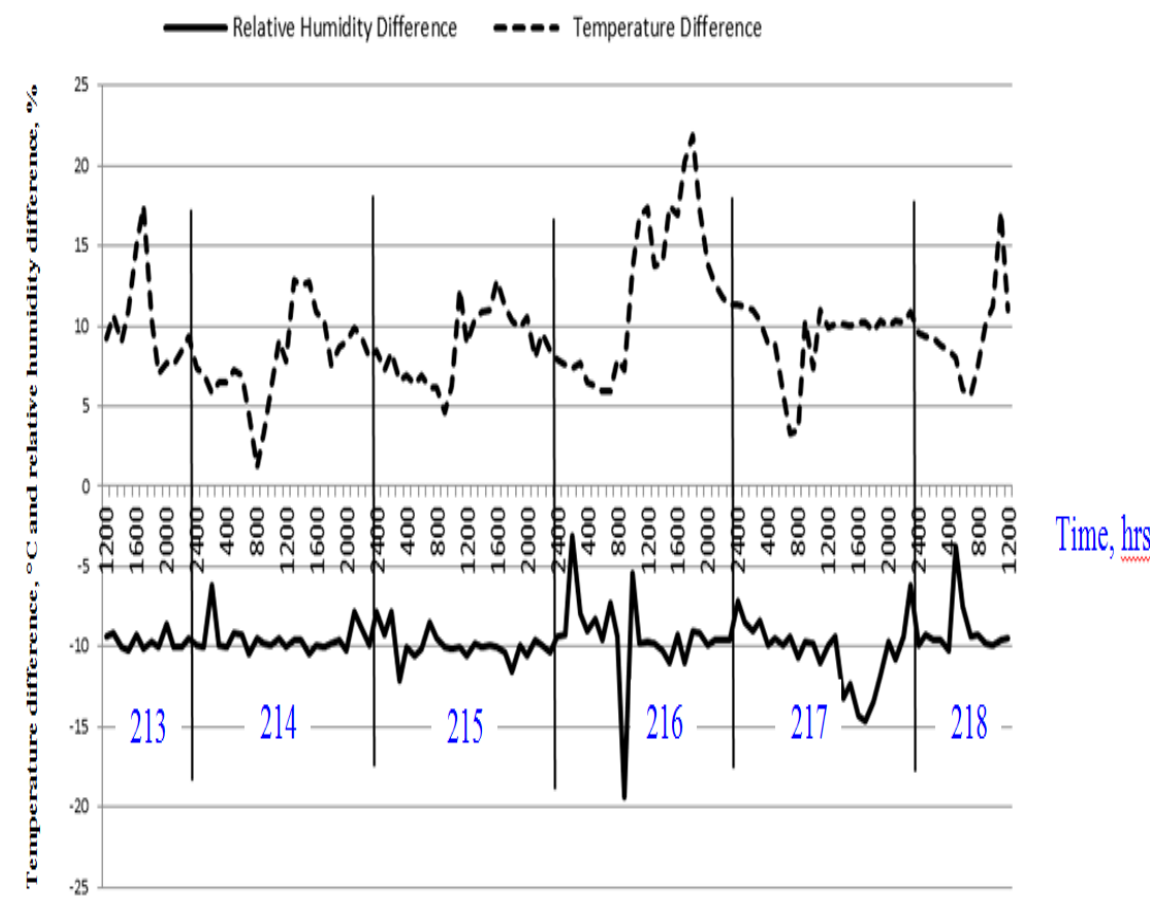

\section{Julian days}

Fig.( 2): Temperature and relative humidity difference inside and outside solar dryer during experiment Julian days

experience in both solar, sun and oven air drying. In this direction Troeger and Butler (1988) indicated that drying time depended primarily upon initial moisture content of products. Drying rate $(\mathrm{Rd})$ in three drying methods was showed in Table (2). The highest drying rate noticed in oven air drying method for both sweet potato and pumpkin samples. Meanwhile, drying rate in sun drying recorded the lowest for sweet potato samples. Drying rate depends upon the rate of moisture migration from the interior of the product to the surface, which naturally depend on the type of material to be dried (Aboltins, 2013).

The maximum temperature reached during the three days of the trial period inside the solar dryer was $51.8^{\circ} \mathrm{C}$ compared to $40.1^{\circ} \mathrm{C}$ outside the dryer (Fig. 2). Meanwhile, the maximum relative humidity reached $78.7 \%$ inside the solar dryer during the three days of trial period compared to $88 \%$ outside the dryer (Fig. 2). These data were in agreement with those of Awady et al (1993) and Yousef and Medany (2007). Those authors reported an elevation in temperature inside the solar dryers from 11 to $28^{\circ} \mathrm{C}$ over the ambient temperatures outside the dryers when drying different types of fruits and vegetables 
Amal A. Matar. et. al.

3-

980 
During the experiment Julian day time, the inside solar temperature is higher than the outside solar dryer and the maximum temperature difference was as high as $21.8^{\circ} \mathrm{C}$ (Fig. 2). Likewise, the inside relative humidity is lower than the outside solar dryer and maximum difference was as high as $19.4 \%$ (Fig. 2). The higher inside temperature and lower relative humidity is the suitable condition for drying.

The three drying methods used greatly affected the drying characteristics of tested samples. The solar dryer was found to be more efficient than the open sun drying. In addition, the samples of solar dryer were completely protected from insects, birds and dusts. These results were in agreement with found by Wankhade et al. (2012).

Data given in (Table 3, 4, 5 and 6) showed the effect of pretreatment, drying methods and storage period at ambient temperature $\left(25^{\circ} \mathrm{C}\right)$ for 6 months on moisture content, total sugar, reducing sugar and citric acid of dried sweet potato and pumpkin, respectively. Results in Table (3) showed that pre-treatment with $15 \%$ sugar solution $(C)$ and $1 \%$ sodium metabisulfite (D) increased water removal and moisture mobility in sweet potato and pumpkin cubes during drying. Decreasing in moisture content of the pretreated sweet potato and pumpkin samples also due to the samples gained sugars and salts by the effect of osmotic dehydration, since the pretreatment was done at $70{ }^{\circ} \mathrm{C}$ for 5 min similar observations were reported by Gierschner et al. (1995) and Olorunda et al.,(1990)

Results, also show that there were significantly increased in moisture content value of treatment B (blanching) compared with control. This increasing for blanching treatment probably occurred because the blanched samples gained moisture during blanching and cooling procedure. These results were in agreement with those found by Cano et al. (1997).

Data in Table (3) indicate that moisture content was lower in oven drying samples compared with sun drying tested samples, because hot air oven drier increased water removal. The results showed that moisture content was higher in solar drying samples compared with sun and solar drying tested samples. These results were in agreement with those of (Ukegbu and Okereke, 2013). The values for moisture contents of all samples were increased during storage period it may be due to absorption of water.

Total sugars are the major constitute of total soluble solids. These sugars are very important parameter in fruit since they directly affects their flavor and taste. Concerning the effect of drying method on the sugar contents of dried sweet potato and pumpkin samples, means of total sugars in Table (4) showed that, there were significant differences $(P \leq 0.05)$ between pretreated and control samples of sweet potato and pumpkin. Total sugar contents were significantly decreased by increasing of storage period time for all samples. Percentages of decreasing of total sugars were higher in pumpkin samples than sweet potato samples. At the end of storage period (6 months), the means percentages of total sugars decreasing were 1.1, 1.7 and $1.14 \%$ for sun, solar and oven dried sweet potato samples, respectively. On the other hand, the decreasing were 3.64, 2.74 and $3.07 \%$ for sun, solar and oven dried pumpkin samples, respectively. 
Amal A. Matar. et. al.

4-

982 
J. Food and Dairy Sci., Mansoura Univ., Vol. 5 (12), December, 2014

$5-$ 
Amal A. Matar. et. al.

Samples treated with sugars $(C)$ were higher in total sugars content than control probably due to sugar gain from soaking solution; also samples treated with sulfating solution were higher in total sugars at zero time. These results may be due to the effect of sulfating treatment which prevents Maillard reaction these values were in agreement with (Bareh et al., 2011).

Differences in reducing sugars content observed during storage period in untreated samples (Table 5). Analysis carried out to test the effect of storage time on the reducing sugar content showed that decreasing reached to $2.5,2.27$ and $2.16 \%$ for sun, solar oven dried sweet potato samples, respectively. While the reducing sugars were $7.23,5.11$ and $6.8 \%$ for sun, solar oven dried pumpkin samples, respectively at the end of storage period. This may attributed to Milliard reaction during storage (Gallali et al., 2000).

The acidity of fruits is considered one of the important quality factors which directly affect their taste through the sugar/acid ratio sugars provides sweet potato and the organic acids sourness. Data represent in Table(6)observed that samples treated with sodium metabisulphate showed more acidity as compared to the other treated samples, while samples treated by blanching had lower acidity for all samples which dried by different drying methods $(P \leq 0.05)$. The increasing in acidity during storage period at ambient temperature $\left(25^{\circ} \mathrm{C}\right)$ observed in dried sweet potato and pumpkin samples in all drying methods.

Organoleptic evaluation for dried sweet potato and pumpkin samples was shown in Table (7). There were highest significant $(P \leq 0.05)$ differences in color scores between all treatment samples for all drying methods. Means of $C$ treatment samples had the highest color score which recorded 8.3 followed by B, D and A treatment for dried sweet potato. Meanwhile, D and C treatment for dried pumpkin samples had the highest score which recorded 7.7 and 7.5 .

In addition, there were no significant different between solar and air drying method while, there is moderate significant different between solar, air and sun drying. The same results were also found for taste score to all treatments tested samples and drying methods.

Also, from the same table, there were moderate significant between all treatments for texture of dried sweet potato for all drying methods. Mean score of $C$ treatments had the highest texture score followed by $B, D$ and $A$ treatments. On the other hand, solar and air drying method had the highest mean of texture score 7.4 and 7.1 followed by sun drying method with moderate significant differences. Sun drying method had the worst mean values of texture compared with the other methods. The same results were also found for odor and acceptability score to all treatments and drying methods. Furthermore, there were high significant to all treatment for acceptability, odor and texture score to dried pumpkin.

Sweet potato dipped in 15\% sugar solution for $5 \mathrm{~min}$ (C) gave the highest mean score in color, taste, odor, texture and acceptability, for three different drying methods. On the other hand, untreated sweet potato gave the lowest mean score for all drying methods. These results agree with those 
J. Food and Dairy Sci., Mansoura Univ., Vol. 5 (12), December, 2014

6-

985 
Amal A. Matar. et. al.

obtained by (Sra and Sandhu, 2011) they reported that untreated dried carrot had the lowest score for sensory evaluation.

No significant differences in sweet potato treated with blanching or sodium metabisulphite for sensory parameters. In addition, there were high significant differences between sun, solar and air drying methods for acceptability, odor and texture score.

Pumpkin dipped in $15 \%$ sugar solution for 5 min (C) which dried by air drying gave the highest score in color, taste, odor, texture, and acceptability. On the other hand, pumpkin without treated (A) gave the lowest score for color, taste, odor and acceptability. In addition, blanching had the lowest score for odor. These results are similar with those obtained by (Yousef and Medany, 2007) they reported that the solar dried fruit samples were better than oven drying. Solar and air drying methods were better than sun drying for sensory parameters. These results are similar with those obtained by (Yousef and Medany, 2007) they reported that the solar dried samples were better than oven drying.

Table (7): Effect of different treatments on sensory evaluation of dried sweet potato and pumpkin

\begin{tabular}{|c|c|c|c|c|c|c|c|c|}
\hline \multirow[b]{2}{*}{ Treatments } & \multicolumn{3}{|c|}{ Dried sweet potato } & \multirow[b]{2}{*}{ Means } & \multicolumn{3}{|c|}{ Dried pumpkin } & \multirow[b]{2}{*}{ Means } \\
\hline & $\begin{array}{c}\text { Sun } \\
\text { drying }\end{array}$ & $\begin{array}{l}\text { Solar } \\
\text { drying }\end{array}$ & Air drying & & $\begin{array}{c}\text { Sun } \\
\text { drying }\end{array}$ & $\begin{array}{l}\text { Solar } \\
\text { drying }\end{array}$ & $\begin{array}{c}\text { Air } \\
\text { drying }\end{array}$ & \\
\hline & \multicolumn{7}{|c|}{ Color } & \\
\hline$A$ & $6.4 \pm 0.516$ & $7.6 \pm 0.516$ & $6.8 \pm 0.789$ & $6.9^{\mathrm{C}}$ & $7.7 \pm 0.674$ & $6.5 \pm 0.671$ & $6.4 \pm 1.06$ & $6.9^{\mathrm{d}}$ \\
\hline$B$ & $7.1 \pm 0.568$ & $7.7 \pm 0.823$ & $8.1 \pm 0.876$ & $7.6^{\mathrm{b}}$ & $7.0 \pm 0.789$ & $7.6 \pm 0.738$ & $7.3 \pm 0.675$ & $7.3^{\mathrm{c}}$ \\
\hline C & $7.9 \pm 0.316$ & $8.3 \pm 0.675$ & $8.9 \pm 0.568$ & $8.3^{\mathrm{a}}$ & $6.2 \pm 0.816$ & $8.0 \pm 816$ & $8.3 \pm 0.823$ & $7.5^{\mathrm{b}}$ \\
\hline D & $6.6 \pm 0.516$ & $7.3 \pm 0.949$ & $7.4 \pm 0.843$ & $7.1^{b}$ & $7.2 \pm 0.738$ & $7.9 \pm 0.316$ & $8.0 \pm 1.42$ & $7.7^{\mathrm{a}}$ \\
\hline \multirow[t]{2}{*}{ Means } & $7.0^{\mathrm{b}}$ & $7.7^{\mathrm{a}}$ & $7.8^{\mathrm{a}}$ & & $7.03^{b}$ & $7.5^{\mathrm{a}}$ & $7.5^{\mathrm{a}}$ & \\
\hline & \multicolumn{7}{|c|}{ Taste } & \\
\hline$A$ & $6.5 \pm 0.849$ & $7.3 \pm 0.483$ & $7.0 \pm 0.816$ & $6.9^{c}$ & $5.8 \pm 0.632$ & $5.6 \pm 0.527$ & $5.3 \pm 0.823$ & $5.57^{d}$ \\
\hline$B$ & $6.6 \pm 0.699$ & $6.6 \pm 0.699$ & $7.1 \pm 0.738$ & $6.7^{b}$ & $5.9 \pm 0.316$ & $6.2 \pm 0.527$ & $6.4 \pm 0.515$ & $6.17^{b}$ \\
\hline C & $7.0 \pm 0.667$ & $8.3 \pm 0.671$ & $8.3 \pm 0.675$ & $7.8^{\mathrm{a}}$ & $8.1 \pm 0.316$ & $8.3 \pm 0.816$ & $8.5 \pm 0.527$ & $8.3^{a}$ \\
\hline $\mathrm{D}$ & $6.4 \pm 0.516$ & $7.3 \pm 0.738$ & $6.7 \pm 0.823$ & $6.7^{\circ}$ & $5.9 \pm 0.568$ & $6.2 \pm 0.823$ & $6.3 \pm 0.483$ & $6.13^{c}$ \\
\hline \multirow[t]{2}{*}{ Means } & $6.6^{b}$ & $7.3^{\mathrm{a}}$ & $7.2^{\mathrm{a}}$ & & $6.43^{c}$ & $6.58^{b}$ & $6.63^{a}$ & \\
\hline & \multicolumn{7}{|c|}{ Odor } & \\
\hline$A$ & $6.2 \pm 0.632$ & $7.2 \pm 0.789$ & $6.4 \pm 1.17$ & $6.6 b$ & $7.1 \pm 0.876$ & $7.6 \pm 0.483$ & $6.5 \pm 1.71$ & $7.07 \mathrm{~b}$ \\
\hline$B$ & $6.4 \pm 0.699$ & $7.1 \pm 0.568$ & $7.2 \pm 0.788$ & $6.9 \mathrm{~b}$ & $6.5 \pm 0.707$ & $6.8 \pm 1.1$ & $7.2 \pm 1.54$ & $5.8 d$ \\
\hline C & $7.6 \pm 0.516$ & $8.1 \pm 0.568$ & $8.0 \pm 0.667$ & $7.9 a$ & $6.5 \pm 0.527$ & $7.5 \pm 0.823$ & $8.0 \pm 816$ & $7.3 \mathrm{a}$ \\
\hline $\mathrm{D}$ & $6.4 \pm 0.516$ & $6.9 \pm 0.875$ & $6.4 \pm 1.17$ & $6.5 b$ & $6.6 \pm 0.699$ & $7.3 \pm 0.713$ & $6.5 \pm 1.35$ & $6.8 \mathrm{c}$ \\
\hline \multirow[t]{2}{*}{ Means } & $6.6 \mathrm{~b}$ & $7.3 a$ & $7.0 \mathrm{a}$ & & $6.68 \mathrm{c}$ & $7.3 \mathrm{a}$ & $7.05 b$ & \\
\hline & \multicolumn{7}{|c|}{ Texture } & \\
\hline$A$ & $6.0 \pm 0.66$ & $7.2 \pm 0.788$ & $7.1 \pm 1.1$ & $6.7^{\circ}$ & $7.3 \pm 0.483$ & $7.2 \pm 0.788$ & $7.1 \pm 1.1$ & $7.2^{\mathrm{C}}$ \\
\hline $\mathrm{B}$ & $6.4 \pm 0.692$ & $6.9 \pm 0.737$ & $7.3 \pm 0.823$ & $6.8^{\circ}$ & $7.1 \pm 0.527$ & $7.5 \pm 0.788$ & $6.9 \pm 1.1$ & $7.17^{\mathrm{C}}$ \\
\hline C & $6.8 \pm 0.632$ & $7.5 \pm 0.849$ & $8.3 \pm 0.823$ & $7.5^{\mathrm{a}}$ & $7.5 \pm 0.527$ & $7.9 \pm 0.849$ & $7.7 \pm 0.823$ & $7.7^{\mathrm{a}}$ \\
\hline $\mathrm{D}$ & $6.1 \pm 0.316$ & $7.1 \pm 0.316$ & $7.0 \pm 1.6$ & $6.7^{\mathrm{b}}$ & $7.3 \pm 0.823$ & $7.5 \pm 0.483$ & $7.4 \pm 0.966$ & $7.4^{\mathrm{b}}$ \\
\hline \multirow[t]{2}{*}{ Means } & $6.3^{b}$ & $7.1^{\mathrm{a}}$ & $7.4^{\mathrm{a}}$ & & $7.2^{\mathrm{C}}$ & $7.53^{\mathrm{a}}$ & $7.27^{\circ}$ & \\
\hline & \multicolumn{7}{|c|}{ Acceptability } & \\
\hline$A$ & $6.8 \pm 0.666$ & $7.5 \pm 0.788$ & $7.3 \pm 1.10$ & $7.2^{b}$ & $6.8 \pm 0.483$ & $7.4 \pm 0.783$ & $7.5 \pm 1.19$ & $7.2^{\mathrm{d}}$ \\
\hline$B$ & $6.7 \pm 0.699$ & $7.7 \pm 0.737$ & $7.8 \pm 0.823$ & $7.4^{\mathrm{b}}$ & $6.5 \pm 0.876$ & $7.6 \pm 0.823$ & $7.9 \pm 1.10$ & $7.3^{\mathrm{C}}$ \\
\hline C & $7.8 \pm 0.632$ & $7.9 \pm 0.844$ & $8.9 \pm 0.823$ & $8.2^{\mathrm{a}}$ & $6.6 \pm 0.527$ & $8.6 \pm .966$ & $8.4 \pm 823$ & $7.87^{\mathrm{a}}$ \\
\hline $\mathrm{D}$ & $6.7 \pm 0.316$ & $7.6 \pm 0.316$ & $7.3 \pm 1.63$ & $7.2^{b}$ & $6.8 \pm 0.823$ & $7.9 \pm .866$ & $8.1 \pm .966$ & $7.6^{b}$ \\
\hline Means & $7.0^{\circ}$ & $7.6^{\mathrm{a}}$ & $7.8^{\mathrm{a}}$ & & $6.67^{\mathrm{C}}$ & $7.87^{0}$ & $7.97^{\mathrm{a}}$ & \\
\hline
\end{tabular}

${ }^{a, b}$ and ${ }^{c}$ means in the same column within the same item followed by different superscripts differ significantly at $p<0.05$.

A = Untreated (control)

$\mathrm{B}=$ Blanched for 4-5 min $\mathrm{C}=$ Dipped in sugar solution $15 \%$ for $5 \mathrm{~min}$ at $70{ }^{\circ} \mathrm{C}$

$\mathrm{D}=$ Dipped in $1 \%$ sodium metabisulphite for $2 \mathrm{~min}$ 
From the previous results, solar dryer has proven effective for drying the fresh produce since it has achieved considerable drying environment during day time environment to prevent condensation during the night time. Further, the dried products have retained some color and are safe from contamination of molds, dust, insects and birds.

\section{REFERENCES}

Aboltins, A.(2013). Theoretical study of material drying coefficient. "Engineering for Rural Development". Jelgava: LLU, pp. 153-158.

A.O.A.C. International. (2000). Official methods of analysis (17th Ed.). Maryland, USA.

Akpinar, E. K. and Bicer, Y. (2004). Modeling of the drying of eggplants in thin-layers. International Journal of Food Science and Technology, 39: 1-9.

ASAE. (1991). Conversion of wet bulb to relative humidity. The American Society for Agricultural Engineers, D 271. 2.

Are'valo-Pinedo, A. and Fernanda, E. X. M. (2006). Kinetics of vacuum drying of pumpkin (Cucurbita maxima): Modeling with shrinkage. Journal of Food Engineering, 76(4): 562-567.

Awady, M.N.; Mohamed, S.A.; EL-Sayed, A.S and Hassanain, A.A. (1993). Utilization of solar energy processes of agricultural products. Misr Journal of Agricultural Engineering,10(4):794-803.

Bala, B.K.; Ashraf, M.A.; Uddin, M.A. and Janjai, S. (2005). Experimental and neural network prediction of the performance of a solar tunnel drier for drying jackfruit bulbs and leather. Journal of Food Process Engineering, 28: 552-566.

Bareh, G.F.; Shouk, A.A. and Kassem, S.M. (2011). Technological and biological effects of sodium meta-bisulfite and ascorbic acid on solar dried sheeted tomato. Journal of American science, 7(4): 15-21.

Beaudry, C. (2001). Evaluation of drying methods on osmotically dehydrated cranberries. Unpublished M.Sc. thesis. Montreal, QC: Department of Agricultural and Biosystems Engineering, McGill University.

Bechoff, A.; Dufour, D.; Dhuique-Mayer, C.; Marouzé, C.; Reynes, M. and Westby, A. (2009). Effect of hot air, solar and sun drying treatments on provitamin A retention in orange-fleshed sweet potato. Journal of Food Engineering, 92: 164-171.

Bilbao-Sainz, C.; Anders, A. and Fito, P. (2005). Hydration kinetics of dried apple as affected by drying condition. Journal of Food Engineering, 68: 369-376.

Cano, P. C.; Deancos, b.; Lobo, M. G. and Santos, M. (1997). Improvement of frozen banana (Musa caverdi shii, Cv Enana) colour by blanching : relationship between browning, phenols and polyphenol oxidase and peroxidase activities. Zeitschrift fur Lebensmittel Untersuchung and Forschung A. Food Research and Technology, 204: 60-65. 
Amal A. Matar. et. al.

Chen, H.H.; Hernandez, C.E. and Huang, T.Z. (2005). A study of the drying effect on lemon slices using a closed-type solar dryer. Solar Energy, 78: $97-103$.

D'ýaz-Medina, E.M.; Rodrýguez-Rodrýguez, E.M. and Dýaz-Romero, C. (2007). Chemical characterization of Opuntia dillenii and Opuntia ficus indica fruits. Food Chemistry, 103: 38-45.

Duncan's D. (1955). Multiple range and multiple F test. Biometric., 11: 1-42. Edition ASSOC, Office. Anal. Chem. Arlington.

Ertekin, C. and Yaldiz, O. (2004). Drying of eggplant and selection of a suitable thin layer drying model. Journal of Food Engineering, 63: 349-359.

Gallali, Y.M.; Abujnah, Y.S. and Bannani, F.K. (2000). Preservation of fruits and vegetables using solar drier: a comparative study of natural and solar drying, III; chemical analysis and sensory evaluation data of the dried samples (grapes, figs, tomatoes and onions). Renewable Energy, 19: 203-12.

Gierschner, K.; John, W. and Philippos, S. (1995). Specific modification of cell wall hydrocolloids in a new technique for processing high quality canned vegetables. Deutsche lebensmitel-rund schan, 91:103-109.

Guin'e, R.P.F.; Pinho, S. and Barroca, M.J. (2011). Study of the convective drying of pumpkin (Cucurbita maxima). Food and Bioproducts Processing, 89: 422-428.

Hossain, M.A. and Bala, B.K., (2007). Drying of hot chilli using solar tunnel drier. Solar Energy, 81:85-92.

Ishida, H.; Suzuno, H.; Sugiyama, N.; Innami, S.; Tadokoro, T. and Maekawa, A. (2000). Nutritive evaluation on chemical components of leaves stalks and stems of sweet potatoes (Ipomoea batatas poir). Food Chemistry, 68: 359-367.

Jain, D. and Tiwari, G.N. (2004). Effect of greenhouse on crop drying under natural and forced convection. I: Evaluation of convective mass transfer coefficient. Energy Conversion and Management 45: 765783.

Jia, X.; Clements, S. and Jolly, P. (1993). Study of heat pump assisted microwave drying. Drying Technology, 11(7): 1583-1616.

Kiranoudis, C.T.; Tsami, E. and Maroulis, Z.B. (1997). Microwave vacuum drying kinetics of some fruits. Drying Technology 15(10): 2421-2440.

Lusan, E.W. and Rooney, L.W. (2002). Snack foods processing. Chapter 7. CRC Press, Boca Raton, London, New York, Washington, D.C.

Marek, G.; Radzanowska, J.; Danilcenko, H.; Jariene,E. and Cerniauskiene, J. (2008). Quality of Pumpkin Cultivars in Relation to Sensory Characteristics. Notulae Botanicae Horti. Agrobotanici Cluj-Napoca, 36 (1): 73 -79.

McWilliam, Margret. (1997). Sensory Evaluation. In: Foods experimental perspectives. 3rd (Ed). Merrillan Imprint of prentice Hall, upper saddle Rever, New Jersy. pp. 33-67. 
Medany, M.A.; Fynn, R.P.; Abou Hadid, A.F. and Short, T.H. (1996). A comparative study between actual and theoretical evapotranspiration of cucumber, Cucumis sativu, grown in rock wool. Acta Horticulture (ISHS), 434: 301-312.

Murthy, M.V.R. (2009). A review of new technologies, models and experimental investigations of solar driers. Renewable and Sustainable Energy Reviews, 13 (4): 835-844.

Nielson, S.J.; Siega-Riz, A.M. and Popkin, B.M. (2002). Trends in energy intake in U.S. between 1977 and 1996: similar shifts seen across age groups. Obes. Res., 10: 370-378.

Olorunda, O.A.; Aworrh, O.C. and Onuha, C.N. (1990). Upgrading quality of dried tomato: Effect of drying method, conditions and pre-drying treatments. Journal of the Science of Food Agriculture, 52: 447-454.

Reuss, M. (1993). Solar drying in Europe. in proceedings of an expert workshop on drying and conservation with solar energy, Budapest, Hungary.

Rodrigues, A.C.C.; Cunha, L. and Hubinger, C.M. (2003). Rheological properties and colour evaluation of papaya during osmotic dehydration processing. Journal of Food Engineering, 59: 129-135.

Rosa Hemphill1 and Lloyd W. Martin (1992).

Microwave Oven-drying Method for Determining Total Solids of Strawberries. North Willamette Research and Extension Center, Oregon State

University, Aurora, OR 97002

Shi, X.Q. and Maupoey, P.F. (1993). Vacuum osmotic dehydration of fruits. Drying Technology, 11(6): 1429-1442.

SPSS. 1999. Statistical Pakage for Social Science SPSS, Inc. Chicago.

Sra, S.K. and Sandhu, K.S. (2011). Effect of processing parameters on physico-chemical and culinary quality of dried carrot slices. J Food Sci. Technol., 48(2):159-166.

Strauss, R.S. and Pollack, H.A. (2001).Epidemic increase in childhood overweight. Journal of American medical association, 286: 26542848.

Troeqer, J.M. and Butler, J.L. (1988). Peanut drying with solar energy. Trancs. of the ASAE., 23(5): 1250-1260.

Tunde-AKintunde, T.Y.; Afolabi, T.J. and AKintunde, B.O. (2005). Influence of drying methods on drying of bell-pepper (Capsicum annuum). Journal of Food Engineering ,68: 439-442.

Tunde-Akintunde, T.Y. and Ogunlakin, G.O. (2011). Influence of drying conditions on the effective moisture diffusivity and energy requirements during the drying of pretreated and untreated pumpkin. Energy Conversion and Management, 52: 1107-1113.

Ukegbu, P.O. and Okereke, C. J. (2013). Effect of solar and sun drying methods on the nutrient composition and microbial load in selected vegetables, African spinach (Amaranthus hybridus), fluted pumpkin (Telferia occidentalis), and okra (Hibiscus esculentus). Sky Journal of Food Science, 2 (5): 35-40. 
Amal A. Matar. et. al.

Wankhade, P.K.; Sapkal, R.S. and Sapkal, V.S. (2012). Drying characteristics of okra slices using different drying methods by comparative evaluation. Proceedings of the World Congress on Engineering and Computer Science, II WCECS 2012, October 24-26, San Francisco, USA.

Yousef, Nahed S. and Medany, M.A. (2007). Utilization of solar drying in fruit drying. Egypt. J. of Apple. Sci., 22(2A): 263-273.

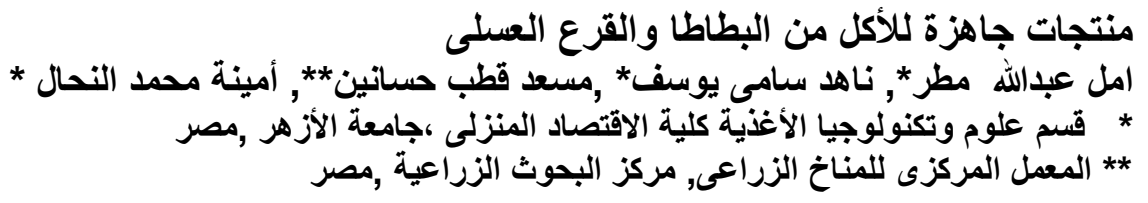

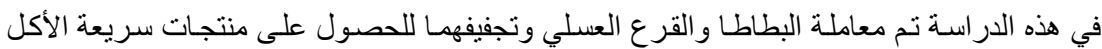

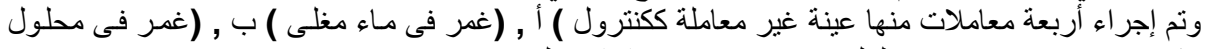

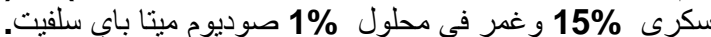

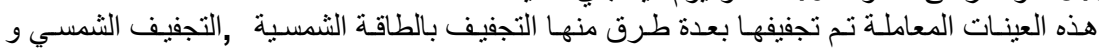

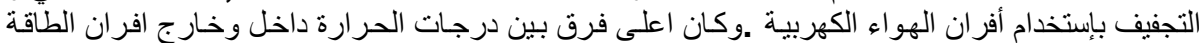

الثمسية 21,8 م .بالمثل كانت الرطوبة النسبية بداخل الافران اقل من مثيلتها بالخارج و واقصى فرق بران بينهما

كان . 19,4\%

و إستغرق التجفيف بالطاقة الثمسية لكل العينات حو الى 58 -52 سـاعة بمحتوى رطوبى للعينات

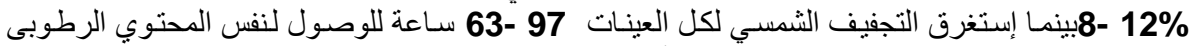

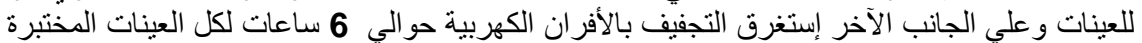

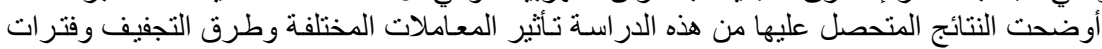

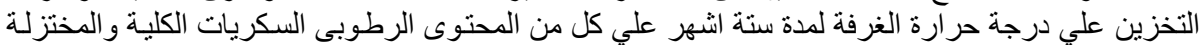

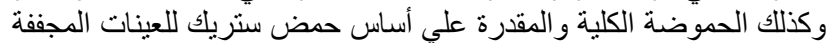

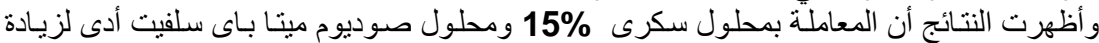

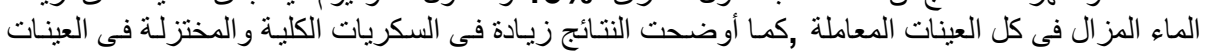

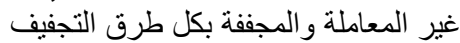

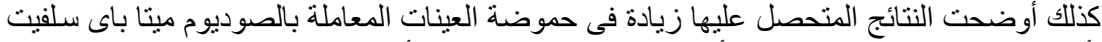

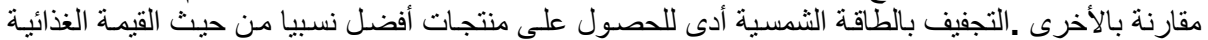

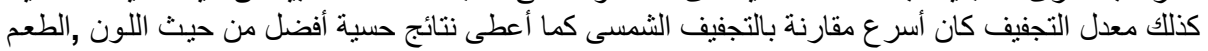

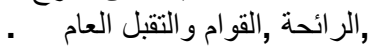


Table (3): Effect of drying methods, pre-treatments and storage periods at ambient temperature $\left(25^{\circ} \mathrm{C}\right)$ on moisture content (\%) of dried pumpkin and sweet potato samples

\begin{tabular}{|c|c|c|c|c|c|c|c|c|c|c|}
\hline \multirow{3}{*}{ Treatments } & \multirow{2}{*}{\multicolumn{4}{|c|}{$\begin{array}{c}\text { Dried sweet potato } \\
\text { Storage period, month }\end{array}$}} & \multirow{3}{*}{ Means } & \multicolumn{4}{|c|}{ Dried pumpkin } & \multirow{3}{*}{ Means } \\
\hline & & & & & & & Storage per & iod, month & & \\
\hline & 0 & 2 & 4 & 6 & & 0 & 2 & 4 & 6 & \\
\hline \multicolumn{11}{|l|}{ Sun dried } \\
\hline A & $10.11 \pm 0.718$ & $10.23 \pm 0.713$ & $10.46 \pm 0.779$ & $10.67 \pm 0.725$ & $10.37^{b}$ & $10.14 \pm 0.713$ & $10.43 \pm 0.843$ & $10.63 \pm 0.299$ & \begin{tabular}{|l|}
$10.92 \pm 0.713$ \\
\end{tabular} & $10.53^{b}$ \\
\hline B & $10.77 \pm 0.721$ & $10.98 \pm 0.418$ & $11.18 \pm 0.239$ & $11.34 \pm 0.618$ & $11.07^{\mathrm{a}}$ & $10.61 \pm 0.559$ & $10.93 \pm 0.483$ & $11.33 \pm 0.379$ & \begin{tabular}{|l|}
$11.57 \pm 0.675$ \\
\end{tabular} & $11.11^{\mathrm{a}}$ \\
\hline $\mathrm{C}$ & $9.03 \pm 0.674$ & $9.25 \pm 0.789$ & $9.46 \pm 0.734$ & $9.77 \pm 0.731$ & $9.38^{\mathrm{d}}$ & $9.50 \pm 0.439$ & $9.71 \pm 0.675$ & $9.92 \pm 0.823$ & $10.13 \pm 0.816$ & $9.82^{\mathrm{c}}$ \\
\hline $\mathrm{D}$ & $9.31 \pm 0.754$ & $9.52 \pm 0.775$ & $9.63 \pm 0.768$ & $9.94 \pm 0.733$ & $9.6^{c}$ & $8.74 \pm 0.692$ & $9.96 \pm 0.713$ & \begin{tabular}{|l|}
$9.19 \pm 0.316$ \\
\end{tabular} & \begin{tabular}{|l|}
$9.43 \pm 0.823$ \\
\end{tabular} & $9.33^{d}$ \\
\hline Means & $9.81^{d}$ & $9.99^{\mathrm{C}}$ & $10.18^{b}$ & $10.43^{\mathrm{a}}$ & & $9.75^{\mathrm{d}}$ & $10.26^{c}$ & $10.31^{b}$ & $10.5^{\mathrm{a}}$ & \\
\hline \multicolumn{11}{|l|}{ Solar dried } \\
\hline A & $10.44 \pm 0.711$ & $10.36 \pm 0.512$ & $10.75 \pm 0.567$ & $10.94 \pm 0.647$ & $10.62^{b}$ & $10.29 \pm 0.816$ & $10.53 \pm 0.619$ & \begin{tabular}{|l|}
$10.79 \pm 0.649$ \\
\end{tabular} & \begin{tabular}{|l|}
$10.92 \pm 0.713$ \\
\end{tabular} & $10.36^{5}$ \\
\hline$B$ & $11.20 \pm 0.754$ & $11.36 \pm 0.617$ & $11.5 \pm 0.527$ & $11.68 \pm 0.644$ & $11.44^{\mathrm{a}}$ & $10.84 \pm 0.689$ & $11.07 \pm 0.675$ & $11.35 \pm 0.816$ & $11.65 \pm 0.483$ & $11.23^{\mathrm{a}}$ \\
\hline $\mathrm{C}$ & $9.41 \pm 0.773$ & $9.57 \pm 0.713$ & $9.74 \pm 0.675$ & $9.95 \pm 0.647$ & $9.67^{\circ}$ & $9.62 \pm 0.483$ & $9.82 \pm 0.599$ & $10.05 \pm 0.713$ & \begin{tabular}{|l|}
$10.29 \pm 0.499$ \\
\end{tabular} & $9.94^{c}$ \\
\hline D & $9.24 \pm 0.767$ & $9.43 \pm 0.671$ & $9.59 \pm 0.555$ & $9.8 \pm 0.623$ & $9.52^{c}$ & $8.86 \pm 0.699$ & $9.12 \pm 0.823$ & $9.36 \pm 0.675$ & $9.59 \pm 0.629$ & $9.23^{d}$ \\
\hline Means & $10.07^{\mathrm{d}}$ & $10.18^{c}$ & $10.39^{b}$ & $10.59^{\mathrm{a}}$ & & $9.97^{d}$ & $10.14^{\mathrm{C}}$ & $10.27^{b}$ & $10.47^{\mathrm{a}}$ & \\
\hline \multicolumn{11}{|l|}{ Oven dried } \\
\hline$A$ & $9.24 \pm 0.542$ & $9.45 \pm 0.634$ & $9.64 \pm 0.533$ & $9.86 \pm 0.534$ & $9.55^{b}$ & $9.41 \pm 0.316$ & $9.63 \pm 0.675$ & \begin{tabular}{|l|}
$9.92 \pm 0.713$ \\
\end{tabular} & $10.12 \pm 0.816$ & $9.77^{\circ}$ \\
\hline$B$ & $9.63 \pm 0.611$ & $9.84 \pm 0.612$ & $10.08 \pm 0.647$ & $10.27 \pm 0.645$ & $9.96^{\mathrm{a}}$ & $10.19 \pm 0.713$ & $10.38 \pm 0.699$ & $10.61 \pm 0.675$ & \begin{tabular}{|l|}
$10.85 \pm 0.699$ \\
\end{tabular} & $10.51^{\mathrm{a}}$ \\
\hline C & $8.32 \pm 0.647$ & $8.53 \pm 0.675$ & $8.76 \pm 0.675$ & $8.95 \pm 0.575$ & $8.64^{c}$ & $8.39 \pm 0.483$ & $8.29 \pm 0.823$ & \begin{tabular}{|l|}
$8.49 \pm 0.699$ \\
\end{tabular} & \begin{tabular}{|l|}
$8.72 \pm 0.823$ \\
\end{tabular} & $8.47^{\circ}$ \\
\hline $\mathrm{D}$ & $8.12 \pm 0.675$ & $8.42 \pm 0.657$ & $8.61 \pm 0.665$ & $8.80 \pm 0.675$ & $8.49^{\mathrm{d}}$ & $8.33 \pm 0.699$ & $8.53 \pm 0.649$ & \begin{tabular}{|l|}
$8.73 \pm 0.316$ \\
\end{tabular} & \begin{tabular}{|l|}
$8.93 \pm 0.699$ \\
\end{tabular} & $8.63^{\mathrm{d}}$ \\
\hline Means & $8.83^{\mathrm{d}}$ & $9.06^{c}$ & $9.3^{b}$ & $9.47^{a}$ & & $9.08^{d}$ & $9.21^{\mathrm{c}}$ & $9.44^{b}$ & $9.66^{a}$ & \\
\hline
\end{tabular}

$a, b, c$ and ${ }^{d}$ means in the same column and raw within the same item followed by different superscripts differ significantly at $p<0.05$.

A= Untreated (control)

$B=$ Blanched in boiling water for 4-5 min

$\mathrm{C}=$ Dipped in $15 \%$ sugar solution for 5 min at $70^{\circ} \mathrm{C}$

$\mathrm{D}=$ Dipped in $1 \%$ sodium metabisulphite for $2 \mathrm{~min}$ 
Table (4): Effect of drying methods, pre-treatments and storage periods at ambient temperature $\left(25^{\circ} \mathrm{C}\right)$ on total sugar (\%) of dried pumpkin and sweet potato

\begin{tabular}{|c|c|c|c|c|c|c|c|c|c|c|}
\hline \multirow{3}{*}{ Treatments } & \multirow{2}{*}{\multicolumn{4}{|c|}{$\begin{array}{l}\text { Dried sweet potato } \\
\text { Storage period, month }\end{array}$}} & \multirow{3}{*}{ Means } & \multicolumn{4}{|c|}{ Dried pumpkin } & \multirow{3}{*}{ Means } \\
\hline & & & & & & & Storage $\mathrm{F}$ & lod, month & & \\
\hline & 0 & 2 & 4 & 6 & & 0 & 2 & 4 & 6 & \\
\hline \multicolumn{11}{|l|}{ Sun dried } \\
\hline A & $39.13 \pm 0.575$ & $39.04 \pm 0.678$ & $38.86 \pm 0.132$ & $38.65 \pm 0.311$ & $38.92^{\mathrm{c}}$ & $13.90 \pm 0.483$ & $13.73 \pm 0.443$ & $13.49 \pm 0.283$ & $13.09 \pm 0.433$ & $13.55^{\circ}$ \\
\hline $\mathrm{B}$ & $38.54 \pm 0.738$ & $38.47 \pm 0.731$ & $38.35 \pm 0.734$ & $38.13 \pm 0.314$ & $38.37^{\mathrm{d}}$ & $13.22 \pm 0.723$ & $13.08 \pm 0.316$ & $12.94 \pm 0.723$ & $12.71 \pm 0.316$ & $12.99^{d}$ \\
\hline $\mathrm{C}$ & $41.44 \pm 0.438$ & $41.32 \pm 0.723$ & $41.18 \pm 0.316$ & $41.06 \pm 0.376$ & $41.25^{\mathrm{a}}$ & $15.00 \pm 0.816$ & $14.93 \pm 0.788$ & $14.93 \pm 0.528$ & $14.92 \pm 0.816$ & $14.95^{\mathrm{a}}$ \\
\hline $\mathrm{D}$ & $39.49 \pm 0.755$ & $39.31 \pm 0.755$ & $39.19 \pm 0.332$ & $39.05 \pm 0.323$ & $39.26^{6}$ & $13.94 \pm 0.488$ & $13.85 \pm 0.734$ & $13.82 \pm 0.388$ & $13.30 \pm 0.323$ & $13.73^{6}$ \\
\hline Means & $39.65^{\mathrm{a}}$ & $39.54^{b}$ & $39.40^{\circ}$ & $39.22^{\mathrm{d}}$ & & $14.01^{\mathrm{a}}$ & $13.89^{\circ}$ & $13.79^{c}$ & $13.5^{\mathrm{d}}$ & \\
\hline \multicolumn{11}{|l|}{ Solar dried } \\
\hline $\mathrm{A}$ & $39.76 \pm 0.311$ & $39.67 \pm 0.676$ & $39.51 \pm 0.438$ & $39.31 \pm 0.645$ & $39.56^{\circ}$ & $13.94 \pm 0.527$ & $13.78 \pm 0.316$ & $13.62 \pm 0.118$ & $13.42 \pm 0.218$ & $13.69^{\circ}$ \\
\hline $\mathrm{B}$ & $39.04 \pm 0.632$ & $38.95 \pm 0.612$ & $38.77 \pm 0.652$ & $38.57 \pm 0.644$ & $38.83^{\mathrm{d}}$ & $13.4 \pm 0.227$ & $13.26 \pm 0.427$ & $13.14 \pm 0.547$ & $13.06 \pm 0.788$ & $13.22^{\mathrm{d}}$ \\
\hline $\mathrm{C}$ & $41.80 \pm 0.645$ & $41.71 \pm 0.652$ & $41.57 \pm 0.615$ & $41.41 \pm 0.635$ & $41.62^{\mathrm{a}}$ & $15.41 \pm 0.554$ & $15.32 \pm 0.816$ & $15.27 \pm 0.627$ & $15.09 \pm 0.316$ & $15.27^{\mathrm{a}}$ \\
\hline $\mathrm{D}$ & $39.88 \pm 0.675$ & $39.69 \pm 0.734$ & $39.51 \pm 0.732$ & $39.30 \pm$ & $39.59^{\mathrm{b}}$ & $14.20 \pm 0.347$ & $14.07 \pm 0.547$ & $13.89 \pm 0.521$ & $13.81 \pm 0.348$ & $13.99^{5}$ \\
\hline Means & $40.12^{\mathrm{a}}$ & $40.00^{b}$ & $39.84^{\mathrm{C}}$ & $39.65^{\mathrm{a}}$ & & $14.24^{\mathrm{a}}$ & $14.11^{\mathrm{D}}$ & $13.98^{\mathrm{c}}$ & $13.85^{\mathrm{d}}$ & \\
\hline \multicolumn{11}{|l|}{ Ovendried } \\
\hline $\mathrm{A}$ & $39.04 \pm 0.527$ & $38.96 \pm 0.575$ & $38.79 \pm 0.637$ & $38.47 \pm 0.527$ & $38.82^{\circ}$ & $13.39 \pm 0.427$ & $13.27 \pm 0.617$ & $13.16 \pm 0.127$ & $13.14 \pm 0.723$ & $13.24^{\circ}$ \\
\hline B & $38.32 \pm 0.530$ & $38.15 \pm 0.524$ & $37.87 \pm 0.563$ & $37.99 \pm 0.501$ & $38.08^{a}$ & $12.92 \pm 0.527$ & $12.74 \pm 0.511$ & $12.46 \pm 0.812$ & $12.29 \pm 0.483$ & $12.60^{\circ}$ \\
\hline $\mathrm{C}$ & $40.88 \pm 0.544$ & $40.80 \pm 0.687$ & $40.63 \pm 0.577$ & $40.43 \pm 0.537$ & $40.69^{\mathrm{a}}$ & $14.80 \pm 0.621$ & $14.74 \pm 0.527$ & $14.58 \pm 0.443$ & $14.39 \pm 0.518$ & $14.63^{\mathrm{a}}$ \\
\hline $\mathrm{D}$ & $39.20 \pm 0.532$ & $39.01 \pm 0.575$ & $38.87 \pm 0.607$ & $38.75 \pm 0.514$ & $38.96^{b}$ & $13.57 \pm 0.463$ & $13.37 \pm 0.543$ & $13.25 \pm 0.462$ & $13.20 \pm 0.523$ & $13.35^{b}$ \\
\hline Means & $39.36^{\mathrm{a}}$ & $39.23^{\mathrm{b}}$ & $39.04^{\mathrm{c}}$ & $38.91^{\mathrm{d}}$ & & $13.67^{\mathrm{a}}$ & $13.53^{\mathrm{b}}$ & $13.36^{\mathrm{c}}$ & $13.25^{\mathrm{d}}$ & \\
\hline
\end{tabular}

$\mathrm{a}, \mathrm{b}, \mathrm{c}$ and ${ }^{\mathrm{d}}$ means in the same column and raw within the same item followed by different superscripts differ significantly at $\mathrm{p}<0.05$.

$A=$ Untreated (control)

$B=$ Blanched in boiling water for 4-5 min

$\mathrm{C}=$ Dipped in $15 \%$ sugar solution for $5 \mathrm{~min}$ at $70^{\circ} \mathrm{C}$

$\mathrm{D}=$ Dipped in $1 \%$ sodium metabisulphite for $2 \mathrm{~min}$ 
Table (5): Effect of drying methods, pre-treatments and storage periods at ambient temperature $\left(25^{\circ} \mathrm{C}\right)$ on reducing sugar (\%) of dried sweet potato and pumpkin

\begin{tabular}{|c|c|c|c|c|c|c|c|c|c|c|}
\hline \multirow{2}{*}{ Treatments } & \multicolumn{4}{|c|}{$\begin{array}{l}\text { Dried sweet potato } \\
\text { Storage period, month }\end{array}$} & \multirow{2}{*}{ Means } & \multicolumn{4}{|c|}{ Dried pumpkin } & \multirow{2}{*}{ Means } \\
\hline & 0 & 2 & 4 & 6 & & 0 & 2 & $\frac{\operatorname{mon}}{4}$ & 6 & \\
\hline \multicolumn{11}{|l|}{ Sun dried } \\
\hline A & $24.56 \pm 0.674$ & \begin{tabular}{|l|}
$24.37 \pm 0.453$ \\
\end{tabular} & $24.20 \pm 0.554$ & $23.99 \pm 0.621$ & $24.28^{\mathrm{C}}$ & $9.20 \pm 0.836$ & $9.01 \pm 0.472$ & $8.86 \pm 0.422$ & $8.63 \pm 0.463$ & $8.93^{\circ}$ \\
\hline $\mathrm{B}$ & $24.44 \pm 0.454$ & \begin{tabular}{|l|}
$24.24 \pm 0.647$ \\
\end{tabular} & \begin{tabular}{|l|}
$24.05 \pm 0.632$ \\
\end{tabular} & $23.89 \pm 0.675$ & $24.16^{\mathrm{d}}$ & $8.23 \pm 0.826$ & $7.80 \pm 0.776$ & $7.67 \pm 0.323$ & $7.42 \pm 0.844$ & $7.78^{\mathrm{d}}$ \\
\hline $\mathrm{C}$ & $25.24 \pm 0.604$ & \begin{tabular}{|l|}
$25.05 \pm 0.644$ \\
\end{tabular} & \begin{tabular}{|l|}
$24.89 \pm 0.671$ \\
\end{tabular} & $24.72 \pm 0.611$ & $24.98^{\mathrm{a}}$ & $10.23 \pm 0.846$ & $10.11 \pm 0.427$ & $9.88 \pm 0.846$ & $9.62 \pm 0.966$ & $9.96^{\mathrm{a}}$ \\
\hline $\mathrm{D}$ & $24.72 \pm 0.622$ & $24.53 \pm 0.614$ & \begin{tabular}{|l|}
$24.39 \pm 0.744$ \\
\end{tabular} & $24.19 \pm 0.624$ & $24.46^{\mathrm{b}}$ & $9.43 \pm 0.921$ & $9.21 \pm 0.846$ & $9.00 \pm 0.126$ & $8.74 \pm 0.934$ & $9.09^{b}$ \\
\hline Means & $24.74^{a}$ & $24.55^{5}$ & $24.40^{\circ}$ & $24.12^{\mathrm{d}}$ & & $9.27^{a}$ & $9.03^{b}$ & $8.85^{\circ}$ & $8.60^{\circ}$ & \\
\hline \multicolumn{11}{|l|}{ Solar dried } \\
\hline A & $24.26 \pm 0.624$ & $24.07 \pm 0.114$ & $23.85 \pm 0.675$ & $23.66 \pm 0.632$ & $23.96^{\mathrm{C}}$ & $9.29 \pm 0.966$ & $9.06 \pm 0.755$ & $8.97 \pm 0.788$ & $8.81 \pm 0.726$ & $9.03^{\mathrm{c}}$ \\
\hline $\mathrm{B}$ & $24.16 \pm 0.632$ & \begin{tabular}{|l|l|}
$23.97 \pm 0.572$ \\
\end{tabular} & \begin{tabular}{|l|}
$23.81 \pm 0.604$ \\
\end{tabular} & $23.59 \pm 0.675$ & $23.88^{\mathrm{d}}$ & $9.00 \pm 0.510$ & $8.79 \pm 0.214$ & $8.63 \pm 0.762$ & $8.54 \pm 0.348$ & $8.74^{\mathrm{d}}$ \\
\hline $\mathrm{C}$ & $25.72 \pm 0.621$ & \begin{tabular}{|l|}
$25.51 \pm 0.642$ \\
\end{tabular} & \begin{tabular}{|l|}
$25.35 \pm 0.752$ \\
\end{tabular} & $25.17 \pm 0.332$ & $25.44^{\mathrm{a}}$ & $10.53 \pm 0.816$ & $10.34 \pm 0.516$ & $10.17 \pm 0.849$ & $10.03 \pm 0.816$ & $10.27^{\mathrm{a}}$ \\
\hline $\mathrm{D}$ & $24.37 \pm 0.644$ & $24.18 \pm 0.672$ & \begin{tabular}{|l|}
$24.02 \pm 0.685$ \\
\end{tabular} & $23.85 \pm 0.622$ & $24.12^{b}$ & $9.48 \pm 0.716$ & $9.32 \pm 0.816$ & $9.15 \pm 0.729$ & $8.99 \pm 0.816$ & $9.24^{b}$ \\
\hline Means & $24.63^{\mathrm{a}}$ & $24.43^{b}$ & $24.26^{c}$ & $24.07^{\mathrm{d}}$ & & $9.58^{\mathrm{a}}$ & $9.38^{6}$ & $9.23^{\mathrm{c}}$ & $9.09^{d}$ & \\
\hline \multicolumn{11}{|l|}{ Oven dried } \\
\hline A & $24.29 \pm 0.632$ & \begin{tabular}{|l|}
$24.10 \pm 0.866$ \\
\end{tabular} & \begin{tabular}{|l|}
$23.94 \pm 0.814$ \\
\end{tabular} & $23.73 \pm 0.716$ & $24.02^{\mathrm{C}}$ & $9.02 \pm 0.701$ & $8.82 \pm 0.697$ & $8.59 \pm 0.617$ & $8.36 \pm 0.849$ & $8.69^{\circ}$ \\
\hline $\mathrm{B}$ & $24.22 \pm 0.816$ & \begin{tabular}{|l|}
$24.03 \pm 0.716$ \\
\end{tabular} & $23.86 \pm 0.726$ & $23.65 \pm 0.845$ & $23.94^{\mathrm{d}}$ & $8.03 \pm 0.824$ & $7.69 \pm 0.829$ & $7.43 \pm 0.637$ & $7.22 \pm 0.714$ & $7.60^{\circ}$ \\
\hline $\mathrm{C}$ & $25.08 \pm 0.616$ & \begin{tabular}{|l|}
$24.89 \pm 0.876$ \\
\end{tabular} & \begin{tabular}{|l|}
$24.73 \pm 0.845$ \\
\end{tabular} & $24.64 \pm 0.632$ & $24.84^{\mathrm{a}}$ & $10.03 \pm 0.407$ & $9.90 \pm 0.417$ & $9.67 \pm 0.407$ & $9.51 \pm 0.749$ & $9.78^{a}$ \\
\hline $\mathrm{D}$ & $24.62 \pm 0.546$ & \begin{tabular}{|l|}
$24.43 \pm 0.864$ \\
\end{tabular} & \begin{tabular}{|l|}
$24.27 \pm 0.875$ \\
\end{tabular} & $24.06 \pm 0.813$ & $24.34^{\mathrm{b}}$ & $9.35 \pm 0.721$ & $9.09 \pm 0.713$ & $8.96 \pm 0.693$ & $8.77 \pm 0.715$ & $9.04^{b}$ \\
\hline Means & $24.55^{a}$ & $24.36^{b}$ & $24.20^{\circ}$ & $24.02^{\mathrm{d}}$ & & $9.12^{\mathrm{a}}$ & $8.88^{\circ}$ & $8.66^{\circ}$ & $8.5^{\mathrm{d}}$ & \\
\hline
\end{tabular}

a,b,c and ${ }^{\mathrm{d}}$ means in the same column and raw within the same item followed by different superscripts differ significantly at $p<0.05$.

$A=$ Untreated (control)

$B=$ Blanched in boiling water for 4-5 min

C = Dipped in $15 \%$ sugar solution for $5 \mathrm{~min}$ at $70^{\circ} \mathrm{C}$

$\mathrm{D}=$ Dipped in $1 \%$ sodium metabisulphite for $2 \mathrm{~min}$ 
Table (6): Effect of drying methods, pre-treatments and storage periods at ambient temperature $\left(25^{\circ} \mathrm{C}\right)$ )on acidity (\%) as citric acid of dried sweet potato and pumpkin

\begin{tabular}{|c|c|c|c|c|c|c|c|c|c|c|}
\hline \multirow{3}{*}{ Treatments } & \multirow{2}{*}{\multicolumn{4}{|c|}{$\begin{array}{l}\text { Dried sweet potato } \\
\text { Storage period, month }\end{array}$}} & \multirow{3}{*}{ Means } & \multirow{2}{*}{\multicolumn{4}{|c|}{$\begin{array}{c}\text { Dried pumpkin } \\
\text { Storage period, month }\end{array}$}} & \multirow{3}{*}{ Means } \\
\hline & & & & & & & & & & \\
\hline & 0 & 2 & 4 & 6 & & 0 & 2 & 4 & 6 & \\
\hline \multicolumn{11}{|l|}{ Sun dried } \\
\hline A & $0.29 \pm 0.716$ & $0.50 \pm 0.616$ & $0.58 \pm 0.704$ & $0.66 \pm 0.774$ & $0.51^{\mathrm{c}}$ & $0.29 \pm 0.718$ & $0.43 \pm 0.548$ & $0.63 \pm 0.724$ & $0.81 \pm 0.776$ & $0.52^{\mathrm{c}}$ \\
\hline $\mathrm{B}$ & $0.19 \pm 0.547$ & $0.34 \pm 0.714$ & $0.52 \pm 0.775$ & $0.60 \pm 0.734$ & $0.41^{\mathrm{d}}$ & $0.21 \pm 0.811$ & $0.39 \pm 0.823$ & $0.59 \pm 0.481$ & $0.77 \pm 0.788$ & $0.49^{d}$ \\
\hline $\mathrm{C}$ & $0.31 \pm 0.526$ & $0.52 \pm 0.744$ & $0.59 \pm 0.765$ & $0.70 \pm 0.321$ & $0.53^{0}$ & $0.26 \pm 0.515$ & $0.44 \pm 0.473$ & $0.69 \pm 0.514$ & $0.88 \pm 0.853$ & $0.57^{\circ}$ \\
\hline $\mathrm{D}$ & $0.39 \pm 0.723$ & $0.56 \pm 0.766$ & $0.65 \pm 0.721$ & $0.74 \pm 0.845$ & $0.59^{\mathrm{a}}$ & $0.39 \pm 0.713$ & $0.56 \pm 0.524$ & $0.76 \pm 0.215$ & $0.93 \pm 0.514$ & $0.66^{\mathrm{a}}$ \\
\hline Means & $0.29^{\mathrm{d}}$ & $0.48^{\mathrm{c}}$ & $0.59^{\mathrm{b}}$ & $0.68^{\mathrm{a}}$ & & $0.29^{d}$ & $0.46^{\circ}$ & $0.68^{b}$ & $0.85^{\mathrm{a}}$ & \\
\hline \multicolumn{11}{|l|}{ Solar dried } \\
\hline A & $0.22 \pm 0.635$ & $0.34 \pm 0.723$ & $0.48 \pm 0.695$ & $0.64 \pm 0.732$ & $0.42^{c}$ & $0.22 \pm 0.383$ & $0.38 \pm 0.123$ & $0.58 \pm 0.713$ & $0.73 \pm 0.855$ & $0.48^{\mathrm{c}}$ \\
\hline$B$ & $0.16 \pm 0.745$ & $0.27 \pm 0.714$ & $0.39 \pm 0.567$ & $0.52 \pm 0.778$ & $0.34^{\mathrm{d}}$ & $0.18 \pm 0.778$ & $0.34 \pm 0.788$ & $0.48 \pm 0.723$ & $0.67 \pm 0.422$ & $0.42^{\mathrm{d}}$ \\
\hline $\mathrm{C}$ & $0.23 \pm 0.744$ & $0.38 \pm 0.756$ & $0.52 \pm 0.774$ & $0.73 \pm 0.356$ & $0.47^{0}$ & $0.24 \pm 0.783$ & $0.46 \pm 0.413$ & $0.58 \pm 0.784$ & $0.74 \pm 0.523$ & $0.52^{b}$ \\
\hline $\mathrm{D}$ & $0.28 \pm 0.747$ & $0.47 \pm 0.706$ & $0.64 \pm 0.775$ & $0.83 \pm 0.756$ & $0.56^{a}$ & $0.40 \pm 0.668$ & $0.47 \pm 0.658$ & $0.66 \pm 0.678$ & $0.94 \pm 0.798$ & $0.62^{\mathrm{a}}$ \\
\hline Means & $0.22^{\mathrm{d}}$ & $0.37^{\circ}$ & $0.51^{\mathrm{b}}$ & $0.68^{\mathrm{a}}$ & & $0.26^{\mathrm{a}}$ & $0.41^{\circ}$ & $0.57^{\circ}$ & $0.77^{\mathrm{a}}$ & \\
\hline \multicolumn{11}{|l|}{ Oven dried } \\
\hline A & $0.16 \pm 0.236$ & $0.27 \pm 0.715$ & $0.45 \pm 0.614$ & $0.62 \pm 0.775$ & $0.38^{\mathrm{C}}$ & $0.19 \pm 0.544$ & $0.36 \pm 0.743$ & $0.56 \pm 0.713$ & $0.71 \pm 0.876$ & $0.46^{\circ}$ \\
\hline B & $0.11 \pm 0.777$ & $0.21 \pm 0.775$ & $0.40 \pm 0.644$ & $0.52 \pm 0.747$ & $0.31^{\mathrm{d}}$ & $0.16 \pm 0.445$ & $0.33 \pm 0.776$ & $0.43 \pm 0.832$ & $0.61 \pm 0.830$ & $0.38^{\mathrm{c}}$ \\
\hline $\mathrm{C}$ & $0.19 \pm 0.706$ & $0.32 \pm 0.767$ & $0.48 \pm 0.563$ & $0.64 \pm 0.714$ & $0.41^{b}$ & $0.21 \pm 0.713$ & $0.39 \pm 0.523$ & $0.58 \pm 0.847$ & $0.72 \pm 0.516$ & $0.48^{b}$ \\
\hline $\mathrm{D}$ & $0.22 \pm 0.694$ & $0.38 \pm 0.634$ & $0.54 \pm 0.506$ & $0.69 \pm 0.722$ & $0.48^{\mathrm{a}}$ & $0.28 \pm 0.417$ & $0.42 \pm 0.854$ & $0.63 \pm 0.802$ & $0.78 \pm 0.875$ & $0.53^{\mathrm{a}}$ \\
\hline Means & $0.17^{\mathrm{d}}$ & $0.29^{\circ}$ & $0.47^{\mathrm{D}}$ & $0.62^{\mathrm{a}}$ & & $0.21^{\mathrm{a}}$ & $0.38^{6}$ & $0.55^{\mathrm{c}}$ & $0.71^{\mathrm{d}}$ & \\
\hline
\end{tabular}

$\mathrm{a}, \mathrm{b}, \mathrm{c}$ and ${ }^{\mathrm{d}}$ means in the same column and raw within the same item followed by different superscripts differ significantly at $\mathrm{p}<0.05$.

A= Untreated (control)

$B=$ Blanched in boiling water for 4-5 min

$\mathrm{B}=$ Blanched in boiling water for $4-5 \mathrm{~min}$. $70^{\circ} \mathrm{C}$

$\mathrm{D}=$ Dipped in $1 \%$ sodium metabisulphite for $2 \mathrm{~min}$ 
J. Food and Dairy Sci., Mansoura Univ., Vol. 5 (12), December, 2014 